Research Article

\title{
Identification and Pathogenicity of Fungal Pathogens Associated with Stem End Rots of Avocado Fruits in Kenya
}

\author{
E. K. Wanjiku, ${ }^{1,2}$ J. W. Waceke, ${ }^{1}$ B. W. Wanjala ${ }^{D},{ }^{3}$ and J. N. Mbaka ${ }^{4}$ \\ ${ }^{1}$ Department of Agriculture Science and Technology, Kenyatta University (KU), Nairobi, Kenya \\ ${ }^{2}$ Department of Animal Health and Production, Mount Kenya University (MKU), Nairobi, Kenya \\ ${ }^{3}$ Biotechnology Research Institute, Kenya Agricultural and Livestock Research Organization (KALRO), Nairobi, Kenya \\ ${ }^{4}$ Horticulture Research Institute, Kenya Agricultural and Livestock Research Organization (KALRO), Nairobi, Kenya \\ Correspondence should be addressed to B. W. Wanjala; bramwelwanjala@yahoo.com
}

Received 29 November 2019; Revised 5 June 2020; Accepted 11 June 2020; Published 9 July 2020

Academic Editor: Giuseppe Comi

Copyright @ 2020 E. K. Wanjiku et al. This is an open access article distributed under the Creative Commons Attribution License, which permits unrestricted use, distribution, and reproduction in any medium, provided the original work is properly cited.

\begin{abstract}
Losses associated with stem end rot (SER) of avocado fruits have been reported in all avocado growing regions of the world. In Kenya, mature avocado fruits present SER symptoms during storage and marketing, but the disease causal agent(s) has not been established. This study aimed to identify the fungal pathogen(s) associated with avocado SER in Kenya and evaluate its pathogenicity. Fungal isolates were collected from symptomatic avocado fruits from randomly selected orchards and major markets within Murang'a County, a major avocado growing region in Kenya, between September 2017 and March 2018. A total of 207 and 125 fungal isolates, recovered from orchards and major markets, respectively, were identified morphologically and further confirmed by molecular techniques. The identified isolates were Lasiodiplodia theobromae (39.8\%), Neofusicoccum parvum (24.4\%), Nectria pseudotrichia (18.4\%), Fusarium solani (7.2\%), F. oxysporum (5.1\%), F. equiseti (3.9\%), and Geotricum candidum (1.2\%). Geotricum candidum was exclusively recovered from fruits from the market. In the pathogenicity test, L. theobromae, $N$. parvum, and N. pseudotrichia caused the most severe SER symptoms. Consequently, they were considered to be the major pathogens of SER of avocado fruits in Kenya. To our knowledge, this is the first report of SER pathogen of avocado fruits in Kenya. Given the significant contribution of avocado fruits to household income and foreign exchange in Kenya, this information is significant to further develop management strategies of postharvest loss of avocado fruits in Kenya.
\end{abstract}

\section{Introduction}

In Kenya, avocado (Persea americana Mill.) is one of the most important perennial tropical fruit crops and a major foreign exchange earner. In 2017, it accounted for about $74 \%$ by value of the total fruits exported from the country [1]. Currently, "Hass" avocado contributes approximately $80 \%$ of the avocado fruits produced and exported from Kenya [2]. Other cultivars produced include "Fuerte," "Puebla," "Duke," and "G6" [3]. Avocado production in Kenya is dominated by smallholder farmers (85\%) within several agroecological zones, who mainly produce for the export market, and the remainder is sold in the local markets. Seventy percent $(70 \%)$ of the avocado fruits are produced in the central and eastern regions of the country. The fruits are exported mainly to the European Union [2, 4]. Since the year
2000, the acreage under avocado production has increased significantly, leading to increased export of the avocado fruit from Kenya [4]. The increased production is fueled by high demand for avocado fruits in the global market due to consumer awareness of the dietary value of the fruit [5]. Despite the increased production and export of avocado fruits from Kenya, high incidences of postharvest fungal diseases, including anthracnose and SER, limit marketing of the fruits and contribute to increased losses by the producers $[6,7]$.

The symptoms of stem end rot (SER) develop on the avocado fruit as it ripens. It is characterized by shriveling, followed by brown to black rot that starts at the stem end of the fruit. As the rot progresses, internal vascular bundles may have black to brown colorations and eventually the whole fruit is consumed by the rot $[8,9]$. Fruits hardly 
display SER symptoms before harvest. Furthermore, SER often occur at the packing house during transit or after marketing.

Various fungal species have been reported to cause SER on avocado fruits. In Chile, the fungal pathogens reported to cause SER included members of Botryosphaeriaceae family, namely Diplodia mutila, D. pseudoseriata, D. seriata, Dothiorella iberica, Lasiodiplodia theobromae, Neofusicoccum australe, N. nonquaesitum, and N. parvum [10]. In Italy, N. parvum, Colletotrichum gloeosporioides, or C. fructicola and Diaporthe foeniculacea or D. sterilis were the most isolated SER pathogens [9]. In California, Neofusicoccum luteum and Phomopsis perseae were reported [8] while in South Africa, Thyronectria pseudotrichia, Dothiorella aromatica, Pestalotiopsis versicolor, Lasiodiplodia theobromae, Rhizopus stolonifer, Fusarium sambucinum, and Fusarium solani were reported [11].

In Kenya, however, the actual pathogen causing SER has not been identified, but on the other hand, anthracnose pathogens have been described [12]. Therefore, this study aimed at identifying the fungal pathogen associated with SER of avocado fruits in the central highlands of Kenya and testing their pathogenicity.

\section{Materials and Methods}

2.1. Study Area and Sample Collection. The study was conducted in Murang'a County, which is the leading county in production and export of avocado fruits in Kenya [1]. Geographically, the county lies between latitudes $0^{\circ} 34^{\prime}$ south and $1^{\circ} 07^{\prime}$ south and longitudes $36^{\circ}$ east and $37^{\circ} 27^{\prime}$ east, with an elevation of $914 \mathrm{~m}$ a.s.l in the east and 3,353 $\mathrm{m}$ a.s.l in the west. Avocado fruits are cultivated in the agroecological zones two, three, and four that have $18.0^{\circ} \mathrm{C}$ to $27.2^{\circ} \mathrm{C}$ average temperature ranges and $1600 \mathrm{~mm}-900 \mathrm{~mm}$ average annual rainfall [13].

Between September 2017 and March 2018, systematic sampling was used to select 162 orchards included in the study. The orchards had more than five "Hass" avocado fruit trees. Six mature avocado fruits were harvested at random from each five randomly selected avocado fruit trees in every sampled orchard. In addition, 10 "Hass" fruits, at different stages of ripening, were bought from different traders in three major markets (Kandara, Kirwara, and Maragwa) within the county at weekly intervals for two months. A total of 453 fruits from 4,860 fruits harvested from the orchards and 240 fruits from the market were sampled, packed in cartons, and transported to Kenya Agricultural and Livestock Research Organization (KALRO), Kandara, where they were incubated at room temperature $\left(22^{\circ} \mathrm{C}-25^{\circ} \mathrm{C}\right)$ for 7-14 days to allow development of SER.

2.2. Fungal Isolation. The 207 fruits from the orchards and 125 fruits from the market that displayed SER symptoms were washed with clean tap water, surface-sterilized with $2 \%$ sodium hypochlorite for one minute, rinsed in distilled water, and air-dried. Small pieces of flesh from the margins of symptomatic flesh were placed aseptically in $9 \mathrm{~cm}$ diameter Petri dishes containing potato dextrose agar (PDA) amended with streptomycin sulfate and incubated at room temperature $\left(22^{\circ} \mathrm{C}-25^{\circ} \mathrm{C}\right)$ for five days. Pure cultures were obtained by transferring the mycelia tips on $1.5 \%$ (wt/vol) water agar (WA) and allowed to grow overnight. Hyphal tips of the mycelia growth in the WA were later transferred onto PDA amended with streptomycin sulfate. Slant universal bottle was used to preserve the pure cultures of the pathogen and stored in the fridge at $4^{\circ} \mathrm{C}$ for later use.

2.2.1. Preparation of Conidial Suspension. Fourteen-day-old pure cultures in PDA were flooded with sterile distilled water. A sterile wire loop was used to scrape off the conidia and bring them to suspension. The suspension was filtered through a double-layer muslin cloth and the collected filtrate diluted serially to $1 \times 10^{5}$. A haemocytometer was used to adjust the spore concentration.

2.3. Morphological Characterization of the Isolate. To induce conidia production, small pieces of mycelia from the isolates were transferred into $9 \mathrm{~cm}$ diameter Petri dishes with PDA amended with autoclaved avocado wood chips and incubated at $25 \pm 1^{\circ} \mathrm{C}$ for four weeks. The isolates were morphologically identified based on cultural and microscopic characteristics as described by Valencia et al. [10], Phillips et al. [14], and Watanabe [15]. Lactophenol blue was used in microscopic identification. The length and width of conidia $(N=50)$ from each isolate were measured using light microscope ZeissPrimo Star, coupled to AxioCam ERc 5s camera.

\subsection{Molecular Characteristics}

2.4.1. DNA Extraction. An improved fungal extraction protocol described by Innis et al. [16] was used to extract DNA from three representative isolates of each species. Pure fungal cultures derived from the single spores incubated in PDA were used. Forty milligram (mg) of mycelium was placed in a microcentrifuge tube containing $300 \mu \mathrm{l}$ of extraction buffer (Tris- $\mathrm{HCl}, 200 \mathrm{mM}$ Ph 8.5; EDTA, $25 \mathrm{mM}$; $1 \mathrm{M} \mathrm{NaCl} 250 \mathrm{mM}$; SDS, 0.5\%) with glass beads. The tubes were placed in a fastprep ${ }^{\circledR}-24$ genogrinder for one minute at $2000 \mathrm{rpm}$. Two hundred microlitre $(\mu \mathrm{l})$ of $3 \mathrm{mM}$ sodium acetate pH5.2 was added and refrigerated at $-20^{\circ} \mathrm{C}$ for 10 minutes. After incubation, the samples were centrifuged for 10 minutes at $13000 \mathrm{rpm}$. After that, the supernatants were transferred into fresh $1.5 \mathrm{ml}$ microcentrifuge tubes. Equal amounts of isopropanol were added to the supernatants and allowed to stand for five minutes at room temperature. After five minutes, the samples were centrifuged for 10 minutes at $13000 \mathrm{rpm}$ and the supernatant was discarded. Five hundred $\mu \mathrm{l}$ of $70 \%$ ethanol was then added to the pellets and centrifuged at $13000 \mathrm{rpm}$ for 10 minutes to wash the pellet. The nucleic acid pellets obtained were air-dried and then resuspended in $50 \mu \mathrm{l}$ of low salt TE buffer (Tris-HCl, $1 \mathrm{mM}, \mathrm{pH}$ 8; EDTA, $0.1 \mathrm{mM}$ ) and stored at $-20^{\circ} \mathrm{C}$ for later use. The quality of DNA was determined by agarose gel electrophoresis and quantified 
using a NanoDrop ND-1000Spectrophotometer. DNA was standardized or normalized to $20 \mathrm{ng} / \mu \mathrm{l}$ for polymerase chain reactions (PCR).

2.4.2. DNA Amplification and Sequencing. The extracted DNA was used as templates in PCR. Two sets of primers, ITS1 (TCCGTAGGTGAACCTGCGG) and ITS4 (TCC TCC GCT TAT TGA TAT GC), ITS5 (GGA AGT AAA AGT CGT $A A C A A G G$ ) and ITS1, were used in the amplification of the internal transcribed region $\mathrm{rDNA}$ of the fungal isolates [16]. PCR reaction volumes of $25 \mu \mathrm{l}$ containing $2.5 \mu \mathrm{l}$ of $0.2 \mu \mathrm{M}$ of each primer, $5 \times$ My Taq reaction buffer, $0.25 \mu \mathrm{l}$ Taq polymerase (Bioline, Meridian Life Science, Memphis, USA), $40 \mathrm{ng} / \mu \mathrm{l}$ of each DNA template, and $12.75 \mu \mathrm{l}$ of molecular water were used. For amplification, the GeneAmp 9700 DNA Thermal Cycler (Perkin-Elmer) was used. The process involved an initial denaturing step at $94^{\circ} \mathrm{C}$ for $30 \mathrm{~s}$, followed by 35 cycles, denaturing at $94^{\circ} \mathrm{C}$ for $30 \mathrm{~s}$, annealing at $55^{\circ} \mathrm{C}$ for $30 \mathrm{~s}$ followed by extension for 1 minute at $68^{\circ} \mathrm{C}$, and a final extension step of $5 \mathrm{~min}$ at $68^{\circ} \mathrm{C}$. To confirm amplification, the PCR products were run on $1.5 \%$ agarose gel and visualized under UV light using ENDURO ${ }^{\mathrm{TM}}$ GDS. The PCR products were cleaned using the Qiagen PCR cleaning kit according to manufacturer instructions and submitted for Sanger sequencing with forward and reverse primers at Inqaba Africa Genomic platform, South Africa.

2.4.3. Bioinformatics Analysis. Sequence data was analyzed by assigning reads to samples, indexes, primers, and adapters. The primers were marked using Picard (https://broadinstitute.github. io/picard/index.html). Bam2fastq (https:/ggl.hudsonalpha.org/ information/software/bam2fastq) was used to convert the resultants' bam files to fastq. The overall sequencing quality of the reads was evaluated visually using the Fast QC program (http:// www.bioinformatics.babraham.ac.uk/projects/fastqc/). The quality parameters used in filtering the reads included a minimum length of $250 \mathrm{bp}$ and a minimum QC value of 30 . Trimming was done corresponding to the adapters and lowquality sequences from all the reads. Subsequent analysis and processing of the reads was done in the CLC Genomic Workbench 11.0, where the overlapping reads were merged. The de novo assembly of the unassembled reads and the raw reads' alignment was performed using CLC Genomics Workbench
11.0 with default parameters (minimum contig $=100 \mathrm{bp}, 23$ K-mer, similarity fraction $=80 \%$, and length fraction $=50 \%$ ). BLAST analysis of the ITS sequences was done to support the morphological identification of the samples at the NCBI database. The ITS sequences were deposited in GeneBank using BankIT.

2.5. Pathogenicity Test. To establish Koch's postulates, Geotrichum candidum, Fusarium equiseti, Fusarium oxysporum, Fusarium solani, Lasiodiplodia theobromae, Neofusicoccum parvum, and Nectria pseudotrichia were subjected to pathogenicity test as described by Freeman et al. [17] and Twizeyimana et al. [8]. Healthy "Hass" fruits were harvested from the farms known to have a low incidence of SER within Murang'a County. The fruits were washed with clean tap water to remove any soil debris. The fruits were surface-sterilized by dipping in $75 \%$ ethanol for about three minutes, rinsed with distilled water, and then air-dried. Each of the isolates was subjected to two methods of inoculation.

A sterile cork borer ( $5 \mathrm{~mm}$ diameter) was used to wound the stem end of each fruit and mycelial discs of equivalent diameter obtained from the edge of actively growing pure cultures were placed on the wound. Six inoculated fruits for each pathogen and six control fruits inoculated with plain PDA were arranged on individual trays and covered with cling film to conserve moisture and avoid contamination. The fruits were incubated at room temperature of $24^{\circ} \mathrm{C} \pm 1$.

After snapping the pedicel of air-dried fruits, conidial suspension $\left(5 \times 10^{-5}\right.$ conidial $\left./ \mathrm{ml}\right)$ was placed on stem end opening and covered with cling film. Six inoculated fruits for each pathogen and six control fruits inoculated with distilled water were arranged in individual trays and covered with cling film. The inoculated fruits were incubated at $24 \pm 1^{\circ} \mathrm{C}$. Evaluation was done after 12 days by cutting the fruits longitudinally and rating SER symptoms on a $0-4$ rating scale as follows: $0=$ no visible rot; $1=1-25 \%$ rot; $2=25-50 \%$ rot; $3=50-75 \% \operatorname{rot} ; 4=\geq 75 \%$ rot (Figure 1 ). At the end of the pathogenicity test, reisolation from the symptomatic fruits was made, and reisolated fungal colonies compared morphologically to the original isolates $[8,9]$. SER severity on avocado fruits was calculated using the following formula [18]:

$$
\text { percent disease index }(\mathrm{PDI})=\frac{\text { sum of numerical ratings }}{\text { no. of fruits examined } \times \text { maximum grade }} \times 100 \text {. }
$$

2.6. Data Analysis. The Sanger sequenced data was analyzed and processed using CLC Genomic Workbench version 11.0. Analysis of Variance (ANOVA) followed by Tukey's post-hoc which was used to compare the mean percentage growth rate of inoculated fungi, while Student's $t$-test was used to compare SER lesions on fruits under different methods of inoculation. Statistical analysis was performed using Min tab v8 (Minitab, LLC).

\section{Results}

3.1. Isolation and Identification of Fungal Species. After incubation of the fruits for 7-14 days, dark brown to black rot developed on the avocado fruits, and fungal mycelia were occasionally observed on the fruit surface. Internally, a discoloration of the vascular bundles was observed (Figure 2). As the fruit ripened, the rot progressed on the 


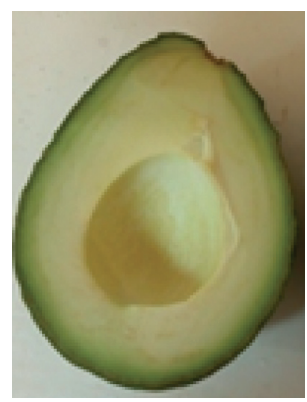

(a)

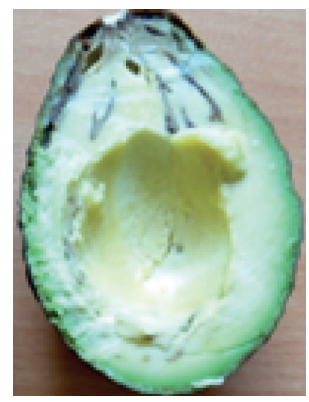

(f)

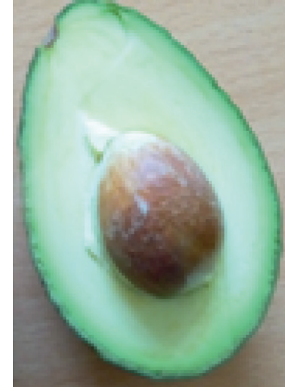

(b)

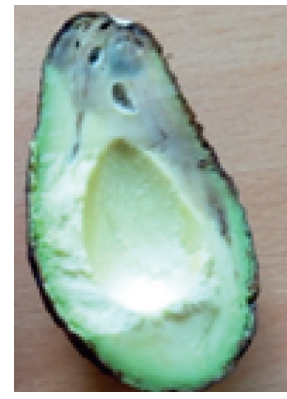

(g)

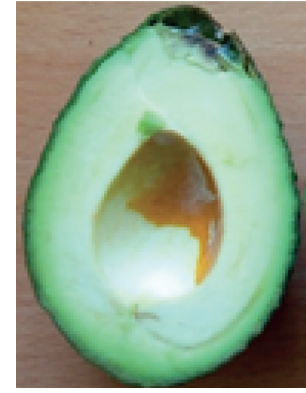

(c)

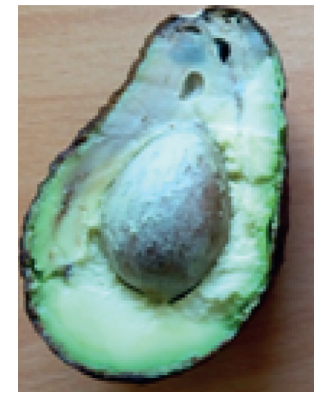

(h)

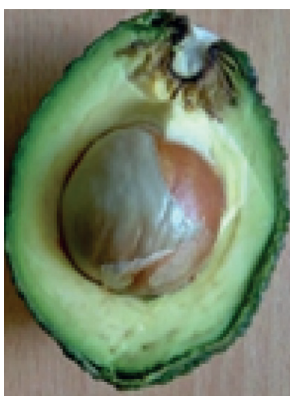

(d)

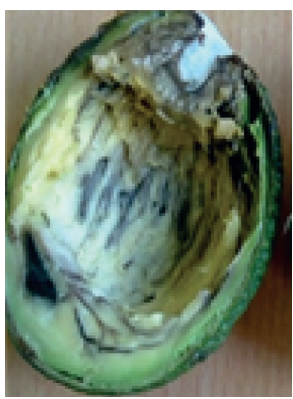

(i)

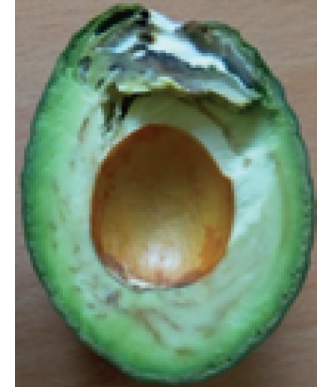

(e)

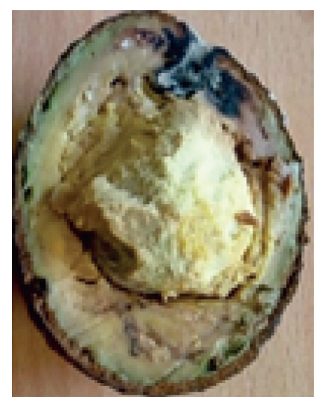

(j)

FIGURE 1: Symptoms of SER on artificial inoculated "Hass" avocado fruits. Guide to severity scoring of the disease rot scale (0-4). (a) and (b) represent 0; (c) and (d) represent 1; (e) and (f) represent 2; (g) and (h) represent 3; (i) and (j) represent 4.

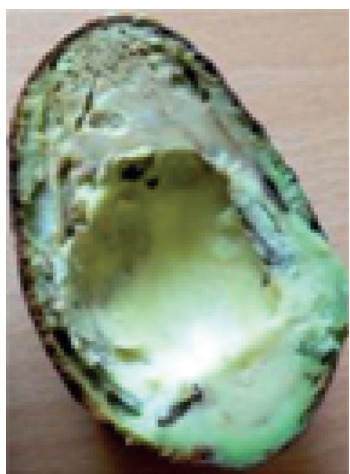

(a)

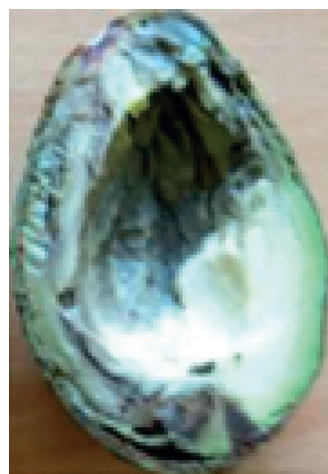

(b)

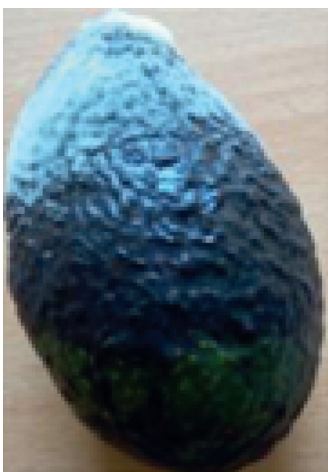

(c)

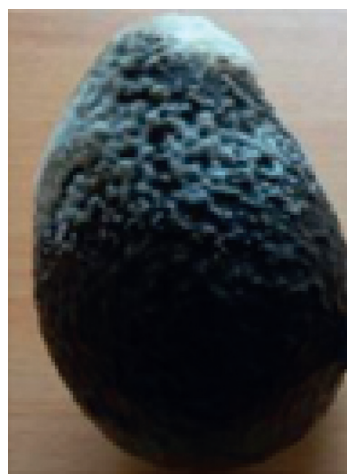

(d)

FIGURE 2: SER symptoms displayed after incubation. (a) brown discoloration of the fruit pulp; (b) black discoloration of the vascular bundles; (c) and (d) fungal mycelia developing on the surface.

whole fruit. A total of 207 isolates were collected from the fruits from the orchards, and 125 isolates were collected from fruits from the markets.

Based on colony and conidial features the isolates were grouped into seven groups (Table 1).

Group 1 Lasiodiplodia theobromae colony on PDA was round and smooth. At first, white aerial filamentous mycelia with grey center developed. With age, colony turned grey and then dark grey to black (Figures 3(a) and 3(b)). The pycnidia were grey in colour and either simple or aggregated. The conidia were subovoid to ellipsoid. Initially, they were aseptate, thick-walled, and hyaline; however, with time, they formed a single medium septum and became dark brown ranging from 17.35 to $29.31 \times 11.23$ to $14.91 \mu \mathrm{m}$ (mean $22.68 \times 5.70 \mu \mathrm{m})$. The morphological characteristics were consistent with what was described by Valencia et al. [10], Phillips et al. [14], and Watanabe [15].

Group 2 Neofusicoccum parvum colony on PDA was rough with irregular margins. Initially, white dense filamentous aerial mycelia developed and turned from dark to black with time (Figures 3(c) and 3(d)). Pycnidia were black, globose, and simple or aggregated. The conidia were bluntly round to subovoid, aseptate, and hyaline with granular content, and with time they turned from light brown to black with a size of 19.77 to $15.25 \times 4.10$ to $7.5 \mu \mathrm{m}$ (mean $17.01 \times 5.70 \mu \mathrm{m})$. The morphological characteristics were consistent with what was described by Valencia et al. [10] and Phillips et al. [14].

Group 3 Nectria pseudotrichia colonies on PDA were white, cottony, with filamentous, aerial mycelia growth. The 
TABLE 1: Isolation frequency of SER associated fungi from avocado fruits obtained from orchards and markets.

\begin{tabular}{|c|c|c|c|c|c|}
\hline \multirow{2}{*}{ Group } & \multirow{2}{*}{ Isolated fungal pathogen } & \multicolumn{2}{|c|}{ Orchards } & \multicolumn{2}{|c|}{ Markets } \\
\hline & & Number of isolates & $\%$ isolation & Number of isolates & $\%$ isolation \\
\hline 1 & Lasiodiplodia theobromae & 82 & 39.6 & 50 & 40.0 \\
\hline 2 & Neofusicoccum parvum & 55 & 26.6 & 26 & 20.8 \\
\hline 3 & Nectria pseudotrichia & 39 & 18.8 & 22 & 17.6 \\
\hline 4 & Fusarium solani & 14 & 6.8 & 10 & 8.0 \\
\hline 5 & F. oxysporum & 10 & 4.8 & 7 & 5.6 \\
\hline 6 & F. equiseti & 7 & 3.4 & 6 & 4.8 \\
\hline 7 & Geotricum candidum & 0 & 0 & 4 & 3.2 \\
\hline & Total & 207 & 100 & 125 & 100 \\
\hline
\end{tabular}

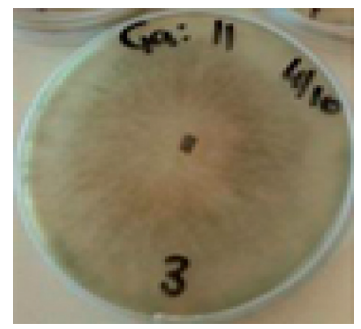

(a)

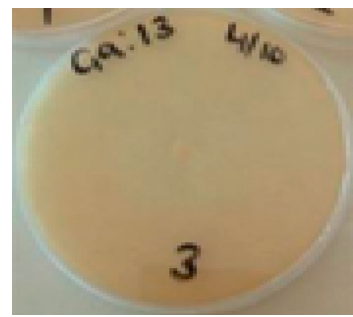

(e)

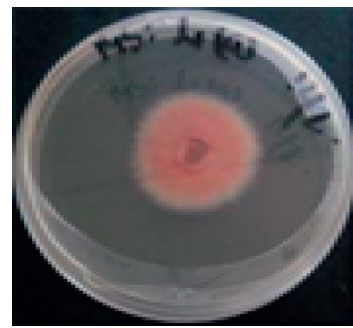

(i)

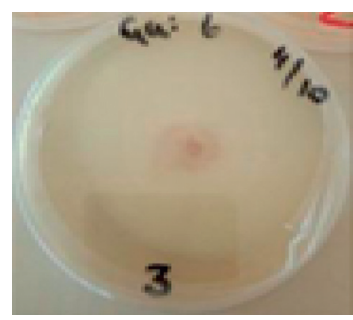

(m)

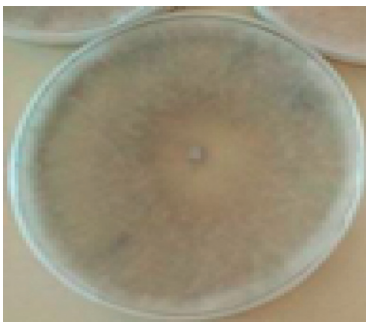

(b)

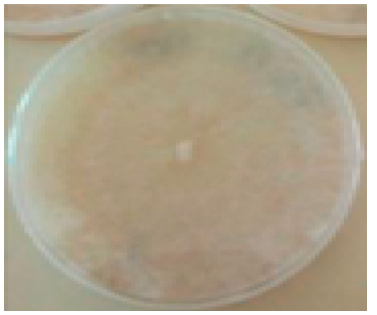

(f)

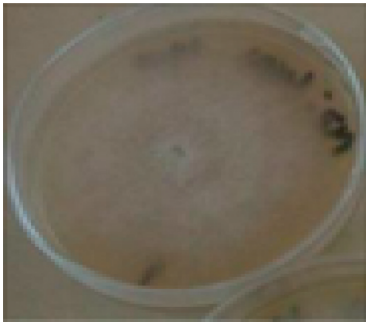

(j)

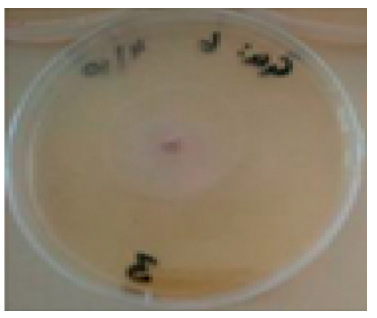

(n)

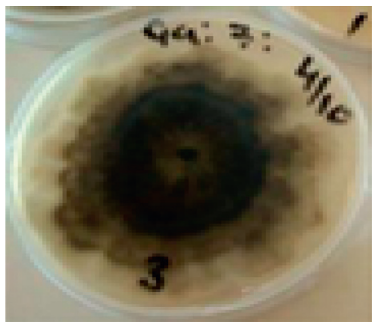

(c)

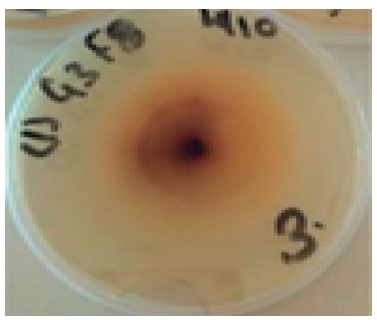

(g)

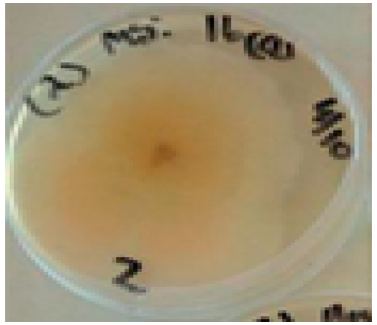

(k)

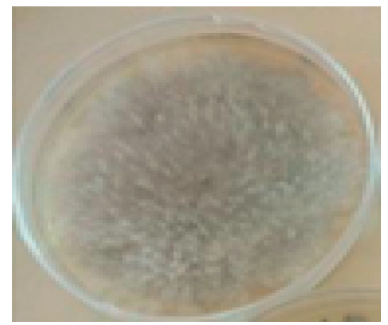

(d)

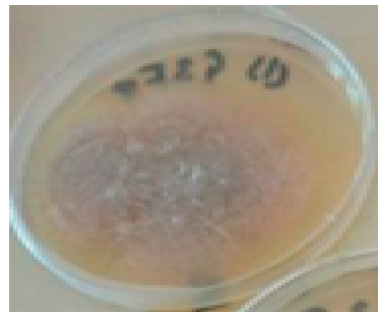

(h)

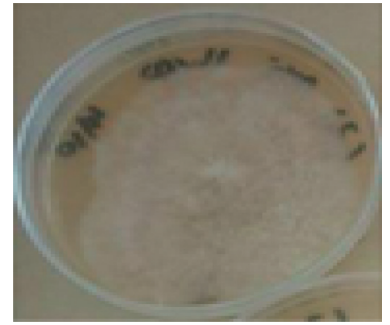

(l)

FIgURE 3: Characteristics of colony (reverse and front) of pathogenic isolates of SER on PDA. (a) and (b) represent reverse and front of Lasiodiplodia theobromae (GA11); (c) and (d) Neofusicoccum parvum (GA7); (e) and (f) Nectria pseudotrichia (GA13); (g) and (h) Fusarium solani (1GEF8); (i) and (j) Fusarium oxysporum (MS4a); (k) and (l) Fusarium equiseti (1GF17); (m) and (n) Geotricum candidum (GA6).

colony growth was regular and rough, with smooth margins (Figures 3(e) and 3(f)). The conidia were ovoid to subovoid with greenish granular content ranging from 6.27 to
$12.50 \times 2.20$ to $9.40 \mu \mathrm{m}$ (mean $8.49 \times 4.95 \mu \mathrm{m}$ ). The morphological characteristics were consistent with what was described by Hirooka et al. [19]. 
Group 4 Fusarium solani colonies on PDA were white, cottony, with floccose mycelium. The colony margins were regular and smooth. The rate of growth was low. The underside was pale to brown in colour (Figures 3(g) and 3(h)). The microconidia were hyaline, oval and some were cylindrical with smooth edges ranging from 5.02 to $8.52 \times 2.91$ to $5.50 \mu \mathrm{m}$ (mean $6.88 \times 3.79 \mu \mathrm{m}$ ), while the macroconidia were hyaline, slightly curved, and broad with two to three septa reaching within 13.05 to $34.18 \times 2.10$ to $5.50 \mu \mathrm{m}$ (mean $18.85 \times 3.36 \mu \mathrm{m})$. The morphological characteristics were consistent with what was described by Hafizi et al. [20] and Watanabe [15].

Group 5 Fusarium oxysporum colonies on PDA were with abundant white to creamy aerial mycelia. The colony margins were smooth and sometimes slightly looped. The reverse side of the colony was pale red to peach violet in colour (Figures 3(i) and 3(j)). Numerous ovoid to kidneyshaped microconidia without septa of 11.2 to $19.9 \times 4.5$ to $8.4 \mu \mathrm{m}$ (mean $15.4 \times 6.1 \mu \mathrm{m}$ ) were produced. The macroconidia were thin-walled, falcate to almost straight, and both ends were almost pointed with 2-3 septa ranging from 22.1 to $43.9 \times 5.1$ to $12.5 \mu \mathrm{m}$ (mean $28.4 \times 7.5 \mu \mathrm{m}$ ). The characteristics were similar to what was observed by Hafizi et al. [20], Hussain et al. [21] and Watanabe [15].

Group 6 Fusarium equiseti colonies on PDA were white, with abundant cottony mycelium that browned with age. Pale to dark brown diffusible pigmentation was observed (Figures 3(k) and 3(l)). The microconidia were not present; however, long and slender slightly curved at the ends with three to six septa macroconidia of 25.3 to $46.7 \times 3.5$ to $4.6 \mu \mathrm{m}$ (mean $37.2 \times 3.24 \mu \mathrm{m}$ ) were observed as similarly observed by Motlagh [22] and Watanabe [15].

Group 7 Geotricum candidum colonies on PDA were not dense and white to beige appressed onto culture medium with smooth margins (Figures $3(\mathrm{~m})$ and $3(\mathrm{n})$ ). The mycelia formed smooth margined arthroconidia, which were hyaline, one-celled, and subglobose or cylindrical with either rounded or truncated apices reaching 6.1 to $19.7 \times 2.3$ to $10.3 \mu \mathrm{m}$ (mean $11.38 \times 5.56 \mu \mathrm{m}$ ). The fungus morphological features were consistent with those described by Zhang et al. [23], Alam et al. [24], and Watanabe [15].

Further more, to support the morphological identification of the samples, molecular markers ITS5 and ITS4 and ITS1 and ITS5 were used for molecular identification and consistently yielded high levels of species discrimination. PCR amplification for the ITS yielded products of 526 to $550 \mathrm{bp}$. From the blast analysis, fungal isolates were able to identify seven species. The isolates reported in this study have been associated with tropical fruits. These included $F$. equiseti (MK922072, MK922069), F. oxysporum (MK922065), F. solani (MK922070, MK922071, MK922066), G. candidum (MK215811, MK922075), L. theobromae (MK922068, MK922073), N. parvum (MK922067), and N. pseudotrichia (MK922074). The closest match between isolates from this study and those mined from the GeneBank had a range from 99 to $100 \%$ similarity and are shown in (Table 2).
TABLE 2: GenBank accession numbers obtained in this study and those from the NCBI GenBank database used in species identification from ITS sequences.

ITS

\begin{tabular}{lcccc} 
Species & Isolate & This study & GenBank & $\begin{array}{c}\text { Percentage } \\
\text { similarity }\end{array}$ \\
\hline F. equiseti & 2MS16a & MK922072 & MG274307 & 99 \\
F. oxysporum & MF17 & MK922069 & & \\
& MS4a & MK922065 & MK590412 & 99 \\
F. solani & MS37a & MK922070 & GQ229075 & 99 \\
& 1G3F8 & MK922066 & KX688164 & 99 \\
G. candidum & GA6a & MK215811 & HG936031 & 99 \\
& GA6 & MK922075 & & \\
L. theobromae & GA11 & MK922068 & KP872340 & 100 \\
N. parvum & KA6 & MK922073 & & \\
N. pseudotrichia & GA7 & MK922067 & HQ832811 & 99 \\
\hline
\end{tabular}

3.2. Pathogenicity Tests. The avocado fruits inoculated with mycelia and those inoculated with spore suspensions developed similar symptoms as observed in fruits obtained from orchards and markets (Figure 1). All the inoculated fruits developed SER symptoms regardless of the isolate or the method of inoculation used. However, disease severity differed across the different fungal species as well as the method of inoculation (Table 3). When inoculated with mycelia, SER severity ranged between $6.67 \%$ and $90.83 \%$ and when spore suspension was used the severity ranged between 97.50\% and $16.67 \%$ (Table 3). Lasiodiplodia theobromae, $N$. parvum, and N. pseudotrichia caused the most severe SER symptoms in both inoculations, and they might be considered the most virulent. No symptoms were observed on the control fruits. Statistical differences $(p<0.05)$ were detected in symptoms development when "Hass" avocado fruits were differentially inoculated with either mycelia or conidial suspensions of N. parvum, N. pseudotrichia, F. solani, F. equiseti, F. oxysporum, and G. candidum. However, there was no statistical significance in symptoms development when inoculated with L. theobromae (Table 3).

\section{Discussion}

We report that avocado SER was caused by Lasiodiplodia theobromae, Neofusicoccum parvum, Nectria pseudotrichia, Fusarium solani, Fusarium oxysporum, Fusarium equiseti, and Geotricum candidum in the central highlands of Kenya. This is the first report on identification of SER fungal pathogens of avocado fruits in Kenya. The identified pathogens have been associated with SER of avocado fruits in other avocado growing regions in the world such as North America (California), Chile, South Africa, and Italy [8-11]. From the current study, L. theobromae was the most frequently isolated pathogen, followed by $N$. parvum and $N$. pseudotrichia. The study corroborates reports by Galsurker et al. [25] that identified L. theobromae as an emerging pathogen of fruits SER worldwide. The pathogen has been associated with SER of mangoes and pawpaw [26, 27] and 
TABLE 3: Severity of SER on "Hass" avocado based on lesion development on fruit, with different fungal pathogens.

\begin{tabular}{|c|c|c|c|}
\hline \multirow[b]{2}{*}{ Isolate } & \multirow[b]{2}{*}{ Species } & \multicolumn{2}{|c|}{ SER on avocado fruits } \\
\hline & & $\begin{array}{c}\text { Mycelia plugs } \\
\% \text { SER }\end{array}$ & $\begin{array}{c}\text { Conidial suspension } \\
\% \text { SER }\end{array}$ \\
\hline MK922068 & Lasiodiplodia theobromae & $81.67 \pm 4.4^{\mathrm{Aa}}$ & $84.17 \pm 9.70^{\mathrm{ABa}}$ \\
\hline MK922067 & Neofusicoccum parvum & $80.83 \pm 2.39^{\mathrm{Ab}}$ & $97.50 \pm 1.12^{\mathrm{Aa}}$ \\
\hline MK922074 & Nectria pseudotrichia & $90.83 \pm 4.55^{\mathrm{Aa}}$ & $74.17 \pm 5.39^{\mathrm{Bb}}$ \\
\hline MK922066 & Fusarium solani & $28.33 \pm 3.80^{\mathrm{Bb}}$ & $60.80 \pm 11.2^{\mathrm{Ca}}$ \\
\hline MK922065 & Fusarium oxysporum & $5.00 \pm 0.00^{\mathrm{Ca}}$ & $19.2 \pm 6.7^{\mathrm{Eb}}$ \\
\hline MK922069 & Fusarium equiseti & $24.17 \pm 0.83^{\mathrm{Bb}}$ & $41.67 \pm 6.91^{\mathrm{Da}}$ \\
\hline MK922075 & Geotricum candidum & $6.67 \pm 1.05^{\mathrm{Cb}}$ & $16.67 \pm 3.07^{\mathrm{Ea}}$ \\
\hline Control & Control & $0.00 \pm 0.00^{\mathrm{C}}$ & $0.00 \pm 0.00^{\mathrm{F}}$ \\
\hline
\end{tabular}

Values were expressed as mean \pm standard error of mean. Values followed by different lowercase superscripts across the rows and different uppercase superscripts along the columns are significantly different at $p<0.05$.

also identified as a major pathogen that causes postharvest disease of many fruits [28].

Further more, results corroborate findings from other avocado growing regions of the world where members of Botryosphaeriaceae family were reported to be the leading cause of SER of avocado fruits. Botryosphaeriaceae species have been reported to cause SER of avocado in South Africa, Italy, California, and New Zealand. In South Africa N. pseudotrichia was the most isolated pathogen, and occasionally, L. theobromae was isolated. In Italy, California, and New Zealand, N. parvum was the most isolated pathogen $[8-11,29]$. Temperatures influence SER pathogen predominant in an area. Botryosphaeriaceae species thrive in high temperature, while water stress stimulates latent infections by the species $[25,30]$. The avocado fruit production in Murang'a County is concentrated in the lower region of the county, characterized by warm weather and temperature ranges between $18.0^{\circ} \mathrm{C}$ and $27.2^{\circ} \mathrm{C}$ [13]. These could explain why L. theobromae and $N$. parvum were the most isolated fungal pathogens.

In California N. parvum and other species of Botryosphaeriaceae (N. australe, N. luteum, Fusicoccum aesculi, and Dothiorella iberica) were associated with SER [8]. However, in our study, only N. parvum was isolated, similar to reports on SER pathogen of avocado fruits in Italy [9]. Three Fusarium species, namely, F. solani, F. oxysporum, and $F$. equiseti, were found to be minor pathogens of SER in Kenya. Similar findings were reported from South Africa, New Zealand [11, 31], and Ethiopia [30]. Geotricum candidum was exclusively isolated from four avocado fruits from the market and never from the orchard fruits. The pathogen has been associated with sour rots of tomatoes, citrus fruits, and vegetables [32]. In the open air markets in Kenya, where the avocado fruits were bought, fruits from avocado, citrus, and other species are placed together, thus allowing for cross-infection between those fruit species.

Colletotrichum gloeosporioides, which have been previously reported as causing SER of avocado in Italy and California $[8,11]$, was not isolated in our study corroborating reports from Chile [10]. Moreover, Twizeyimana et al. [8] identified C. gloeosporioides as a weak avocado SER pathogen and is only important when in combination with other SER pathogens.
Morphological characteristics together with DNA analysis were used to identify and differentiate L. theobromae, N. parvum, and N. pseudotrichia. Lasiodiplodia theobromae grew fast and colonised the Petri dish in two days. Neofusicoccum parvum and N. pseudotrichia colonized the Petri dish in four and five days, respectively. The three pathogens showed almost similar morphological features. However, ITS sequences of these fungi clearly allowed the differentiation of the species.

Lasiodiplodia theobromae was the most isolated pathogen from fruits from both orchards and markets, followed by $N$. parvum and N. pseudotrichia. During pathogenicity studies, the three pathogens also caused the most severe SER on avocado fruits. The three pathogens are, therefore, identified as the main causal agents of avocado SER in Kenya.

Further studies should be conducted in other avocado growing regions in the country to get a clear picture of SER etiology in Kenya. Besides, preharvest and postharvest SER management practices of avocado fruits in the country should be established.

\section{Data Availability}

The data used to support the findings of this study are included in the article.

\section{Conflicts of Interest}

The authors declare that there are no conflicts of interest regarding the publication of this paper.

\section{Acknowledgments}

The authors are grateful to the management of Kenya Agricultural and Livestock Research Organization (KALRO), Kandara and Biotechnology Research Centre, Kabete, for providing the necessary facilities to carry out morphological and molecular studies. The authors also acknowledge Inqaba Biotech., South Africa, for DNA sequencing.

\section{References}

[1] Horticultural Crops Directorate (HCD), Horticultural Crops Production Report HCD, Horticultural Crops Directorate (HCD), Nairobi, Kenya, 2016. 
[2] R. Nyambati and S. Kioko, "Production and utilization of fruit, fodder and bio-energy trees. Kenya's water towers protection and climate change mitigation and adaptation (water) programme," 2018.

[3] Horticultural Crops Directorate (HCD), Horticultural Crops Production Report HCD, Horticultural Crops Directorate (HCD), Nairobi, Kenya, 2017.

[4] E. G. Johnny, J. K. Mariara, R. Mulwa, and G. M. Ruigu, "Smallholder avocado contract farming in Kenya: determinants and differentials in outcomes," African Journal of Economic Review, vol. 7, no. 2, pp. 91-112, 2019.

[5] L. S. Magwaza and S. Z. Tesfay, "A review of destructive and non-destructivemethods for determining avocado fruit maturity," Food and Bioprocess Technology, vol. 8, no. 10, pp. 1995-2011, 2015.

[6] L. A. Wasilwa, J. K. Njuguna, E. N. Okoko, G. W. Watani, and Others, "Status of avocado production in Kenya," 2006, http:// www.kalro.org:8080/repository/handle/1/380.

[7] J. Oduol, F. Place, D. Mithöfer, J. Olwande, L. Kirimi, and M. Mathenge, "Improving participation in agricultural commodity markets for smallholder avocado farmers in Kenya: assessing growth opportunities for women in Kandara and Marani districts," Tegemeo Institute, Egerton University, Nairobi, Kenya, 2013.

[8] M. Twizeyimana, H. Förster, V. McDonald, D. H. Wang, J. E. Adaskaveg, and A. Eskalen, "Identification and pathogenicity of fungal pathogens associated with stem-end rot of avocado in California," Plant Disease, vol. 97, no. 12, pp. 1580-1584, 2013.

[9] V. Guarnaccia, A. Vitale, G. Cirvilleri et al., "Characterisation and pathogenicity of fungal species associated with branch cankers and stem-end rot of avocado in Italy," European Journal of Plant Pathology, vol. 146, no. 4, pp. 963976, 2016.

[10] A. L. Valencia, P. M. Gil, B. A. Latorre, and I. M. Rosales, "Characterization and pathogenicity of botryosphaeriaceae species obtained from avocado trees with branch canker and dieback and from avocado fruit with stem end rot in Chile," Plant Disease, vol. 103, no. 5, pp. 996-1005, 2019.

[11] J. M. Darvas, "Fungi associated with pre-and postharvest diseases of avocado fruit at Westfalia Estate, South Africa," Phytophylactica, vol. 19, no. 1, pp. 83-86, 1987.

[12] S. K. Kimaru, E. Monda, R. C. Cheruiyot, J. Mbaka, and A. Alakonya, "Morphological and molecular identification of the causal agent of anthracnose disease of avocado in Kenya," International Journal of Microbiology, vol. 2018, Article ID 4568520, 10 pages, 2018.

[13] R. Jaetzold, H. Schmidt, B. Hornetz, and C. Shisanya, Farm Management Handbook of Kenya: Volume II: Natural Conditions and Farm Management Information; Part B: Central Kenya; Subpart B1b Northern Rift Valley Province, Ministry of Agriculture, Nairobi, Kenya, 2007.

[14] A. J. L. Phillips, A. Alves, J. Abdollahzadeh et al., "The botryosphaeriaceae: genera and species known from culture," Studies in Mycology, vol. 76, pp. 51-167, 2013.

[15] T. Watanabe, Pictorial Atlas of Soil and Seed Fungi: Morphologies of Cultured Fungi and Key to Species, CRC Press, Boca Raton, FL, USA, 2010.

[16] M. A. Innis, D. H. Gelfand, J. J. Sninsky, and T. J. White, PCR Protocols: A Guide to Methods and Applications, Academic Press, Cambridge, MA, USA, 2012.

[17] S. Freeman, T. Katan, and E. Shabi, "Characterization of Colletotrichum species responsible for anthracnose diseases of various fruits," Plant Disease, vol. 82, no. 6, pp. 596-605, 1998.
[18] B. K. M. Lakshmi, P. N. Reddy, and R. D. Prasad, "Crossinfection potential of Colletotrichum gloeosporioides Penz. Isolates causing anthracnose in subtropical fruit crops," Tropical Agricultural Research, vol. 22, no. 2, pp. 183-193, 2011.

[19] Y. Hirooka, A. Y. Rossman, and P. Chaverri, "A morphological and phylogenetic revision of the Nectria cinnabarina species complex," Studies in Mycology, vol. 68, pp. 35-56, 2011.

[20] R. Hafizi, B. Salleh, and Z. Latiffah, "Morphological and molecular characterization of Fusarium solani and Fusarium oxysporum associated with crown disease of oil palm," Brazilian Journal of Microbiology, vol. 44, no. 3, pp. 959-968, 2013.

[21] M. Z. Hussain, M. A. Rahman, M. N. Islam, M. A. Latif, and M. A. Bashar, "Morphological and molecular identification of Fusarium oxysporum Sch. isolated from guava wilt in Bangladesh," Bangladesh Journal of Botany, vol. 41, no. 1, pp. 49-54, 2012.

[22] M. R. S. Motlagh, "Isolation and characterization of some important fungi from Echinochloa spp. the potential agents to control rice weeds," Australian Journal of Crop Science, vol. 4, no. 6, pp. 457-460, 2010.

[23] L. Zhang, Y. H. Li, X. M. Zhang, Q. H. Zhang, and H. Q. Xian, "First report of sour rot caused by Geotrichum candidum on mori fructus in China," Plant Disease, vol. 102, no. 12, p. 2640, 2018.

[24] M. W. Alam, A. Rehman, A. U. Malik et al., "First report of Geotrichum candidum causing postharvest sour rot of peach in Punjab, Pakistan," Plant Disease, vol. 101, no. 8, p. 1543, 2017.

[25] O. Galsurker, S. Diskin, D. Maurer, O. Feygenberg, and N. Alkan, "Fruit stem-end rot," Horticulturae, vol. 4, no. 4, p. $50,2018$.

[26] J. O. Honger, C. E. William, D. Owusu-Ansah, K. Siaw-Adane, and G. T. Odamtten, "Pathogenicity and fungicide sensitivity of the causal agent of postharvest stem end rot disease of mango in Ghana," Ghana Journal of Agricultural Science, vol. 49 , no. 1, pp. 37-52, 2015.

[27] A. V. D. S. Pereira, R. B. Martins, S. J. Michereff, M. B. D. Silva, and M. P. S. Câmara, "Sensitivity of Lasiodiplodia theobromae from Brazilian papaya orchards to MBC and DMI fungicides," European Journal of Plant Pathology, vol. 132, no. 4, pp. 489-498, 2012.

[28] H. Mohamed and A. Saad, "The biocontrol of postharvest disease (Botryodiplodia theobromae) of guava (Psidium guajava L.) by the application of yeast strains," Postharvest Biology and Technology, vol. 53, no. 3, pp. 123-130, 2009.

[29] W. F. T. Hartill, "Post-harvest diseases of avocado fruits in New Zealand," New Zealand Journal of Crop and Horticultural Science, vol. 19, no. 3, pp. 297-304, 1991.

[30] M. Kebede and A. Belay, "Fungi associated with post-harvest avocado fruit rot at jimma town, southwestern Ethiopia," Journal of Plant Pathology and Microbiology, vol. 10, no. 3, p. 2, 2019.

[31] R. C. Ploetz, Diseases of Tropical Fruit Crops, CABI, Wallingford, UK, 2003.

[32] C. R. Thornton, D. C. Slaughter, and R. M. Davis, "Detection of the sour-rot pathogen Geotrichum candidum in tomato fruit and juice by using a highly specific monoclonal antibodybased ELISA," International Journal of Food Microbiology, vol. 143, no. 3, pp. 166-172, 2010. 